\title{
External Quality Assurance Model in HEIs: 3-D ACS Framework
}

\author{
Maria Magdalena Wahyuni Inderawati ${ }^{1}$, PoTsang B Huang ${ }^{2}$, Ronald Sukwadi ${ }^{3}$ \\ \{wahyuni.inderawati@atmajaya.ac.id ${ }^{1}$,pthuang@cycu.edu.tw ${ }^{2}$,ronald.sukwadi@atmajaya.ac.id $\left.{ }^{3}\right\}$ \\ Industrial Engineering, Atma Jaya Catholic University of Indonesia, Jl. Raya Cisauk Lapan, Sampora, \\ Kec. Cisauk, Tangerang, Banten 15345, Indonesia ${ }^{1,3}$ \\ Industrial and System Engineering, Chung Yuan Christian University, No. 200, Zhongbei Road, Zhongli \\ District, Taoyuan City, 32023 Taiwan ${ }^{1,2}$
}

\begin{abstract}
Based on pre-existing literature, accreditation, customer satisfaction, and education for sustainable development are essential perspectives in measuring tertiary institutions' quality. A preliminary survey was conducted to identify important aspects of determining higher education quality. The results showed the accreditation requirements had already covered almost all aspects; however, it lacked student satisfaction and sustainable development education. The previous studies showed each perspective had been evaluated separately and has advantages and disadvantages. This paper proposes a novel quality framework consisting of three crucial perspectives: Accreditation ranking, Customer satisfaction, and education for sustainable development, which will be correlated with each other to obtain a comprehensive and holistic measure of the quality for a higher education institution. It is called the 3-D ACS Framework. This paper only presents the surface of the 3-D ACS Framework concept. Henceforth, in-depth research must be carried out to provide a more comprehensive concept of measuring higher education quality.
\end{abstract}

Keywords: higher education, quality assurance, 3-D ACS Framework

\section{Introduction}

Higher education institutions around the world are currently experiencing developments and intense competition. Every institution is demanded to have quality. Many studies [1-4] related to the importance of quality assurance in higher education institutions have been conducted in several countries. Studies in European tertiary education institutions have shown that quality assurance is a must. Furthermore, quality assurance should not be carried out in the same way as compulsory technical work or technical work to satisfy the regulations. The essential objective is to make tertiary education competitive, transparent, diversified, and leading globally. Quality assurance would also provide and guarantee high quality research, teaching-learning [1].

Quality assurance in Romanian Higher Education was a legislative matter. Romanian's national system's quality assurance performance depends on the correspondences established between academic quality and transformations in higher education in Romania and worldwide. There were 
three fields in quality assurance provided by the Romanian legislation: (1) the institutional capacity, (2) the educational efficiency, and (3) quality management [2].

A study in Cyprus (2016) observed that the use of a global network system should be more common for the effect of quality assurance studies on the world, competitiveness understanding among higher education should be more comprehensive, also higher education institutions should make everyday decisions in the reaching of quality [3].

Higher education is growing with other improvements, such as increasing technology use in learning innovative partnerships between universities and commercial entities and extending students' access. It also a more critical role in economic and social development in the region and globally. In line with these developments, the quality assurance in higher education has reformed and developed worldwide in the last decade, such that research and teaching in higher education is increasingly a global concern [4].

It has become a norm that accreditation is a crucial indicator in measuring tertiary education institutions' quality. Several advantages and disadvantages emerge in the implementation of accreditation. In general, accreditation for higher education is an obligation that must be carried out by an institution. Many benefits are obtained, for example, to increase students' intake, expand collaboration, and have a good impact on competitiveness [5-8]. However, some higher education institutions perceived that accreditation is a written formality to comply with the government's demands rather than improve the institution's quality itself [9]. Therefore, it is not enough to determine the quality of higher education based only on accreditation.

Another activity that is also popular in implementing quality assurance is measuring customer satisfaction. In this case, feedback from students and alumni is useful for institutions to accomplish continuous improvements and increase their quality [10-13].

In line with the world's development today, it has been proposed that universities need to start paying attention to sustainability development. The role of higher education in achieving sustainable development goals has gradually been adopted as one of the indicators of quality in higher education institutions [14-16].

This paper proposes a new framework to determine quality in higher education. This new framework will provide a more comprehensive idea of quality measurement in higher education based on accreditation, customer satisfaction, and sustainable development education. Thus it is expected that when higher education is declared to be of high quality, it will fulfill three aspects of higher education quality: the perspective of accreditation, customer, and sustainable development.

\section{Literature Review}

\subsection{Accreditation}

Accreditation is standard in higher education quality assurance. Some countries have national accreditation bodies that are tasked with accrediting institutions or programs. In this case, the government usually requires all tertiary educations to follow this accreditation (mandatory), and usually, the costs are borne by the government. Besides, there is also a voluntary accreditation model. Usually carried out by non-profit institutions by the characteristics of the program. Following 
are some examples of independent accreditation bodies: (1) Accreditation Board for Engineering and Technology (ABET), a non-governmental agency accrediting programs in applied and natural science, computing engineering, and engineering technology internationally. ABET accredits programs that have received recognition from national or regional accreditation bodies or national education authorities around the world; (2) Indonesian Accreditation Board for Engineering Education (IABEE) was founded as an autonomous part of the Indonesian Engineers Association (PII) to develop and foster a quality culture in the management of engineering higher education. IABEE accreditation is an international-level accreditation after become signatory of the international accord (Washington Accord for Engineering and Seoul Accord for computing programs). To obtain accreditation from the IABEE, programs must be associated with an institution that has been accredited at least with status B by the Indonesian National Accreditation Body. The programs must be accredited at least with status B (for Provisional accreditation) and at least with status A (for General accreditation) also by the Indonesian National Accreditation Body; (3) Association to Advance Collegiate Schools of Business International (AACSB) provides quality assurance, business education intelligent and professional development services to business schools. To get AACSB accreditation, the school has to become a member and apply for an eligibility application. The eligibility application states that this business school is subject to a national quality assurance regulation from the government or other quality assessment entities. The three examples above demonstrate the requirement to be recognized by the competent national authorities before applying for accreditation.

Previous studies [5, 17-19] stated that the implementation of accreditation policy in private universities positively impacted their competitiveness. It also increased the number of academic qualifications, student intake, facilities, and infrastructure and the cooperation with external parties [6]. The results of research at private higher education institutions in Kota Pakan Baru, Indonesia, showed that in choosing private higher education institutions, prospective students consider accreditation, in addition to the existence of classes for employees, tuition fees, and location [7]. Other studies stated that accreditation was more representative of quality than grade point average (GPA) because accreditation was assessed by external parties [8]. Regarding the issue of internationalization, which is now becoming one of the main priorities of a tertiary education institution worldwide, a study showed that academic quality is the essential things for international students to choose the university, as well as reputation and the presence of international students and staffs [5]. Accreditation is a type of quality assurance that is mandatory for accountability. Accreditation is also a written formal acknowledgment that proves that a higher education institution is compatible with the required standards. Quality assurance will increase university recognition, which impacts equal cooperation, and will further improve student mobility [6].

From the explanation above, it can be concluded that national accreditation is crucial and must be obtained by higher education institutions. Even to get international accreditation, higher education institutions need to receive national recognition first. Thus, it is almost certain that every higher education is required to have national accreditation. However, a study in Omani [7] revealed that the national accreditation a strategically forced tool made under the constraint of accountability rather than an effective mechanism of improvement.

The description above shows that accreditation is essential for quality assurance. Nevertheless, on the condition that accreditation is only perceived as fulfilling government regulations or its nature is voluntary, this is not enough to measure higher education institutions' quality. 


\subsection{Customer satisfaction}

A useful tool for authority decisions to improve the educational policy in feedback mode is monitoring consumers' options of educational services. More accurate and reliable feedback from consumers of educational services could be provided by continuous improvement of public assessment measurement tools [8]. Information for decision-making regarding the quality improvement of the education provided by assessing stakeholders' satisfaction [1].

A study showed a phase of quality management model in higher education base on business process modeling. The paper points out the priority of graduates' satisfaction in assessing quality in higher education institutions. It also acknowledges a critical development that has constructed the idea of correlating the graduates' requirements regarding the developed specific and transversal skills during the study with the labor market's required competencies [9]. University graduates as stakeholders could evaluate their student experiences and the lack of consistency between their training and what employers demand. Complain from students and graduates become inputs to improve university quality [10]. A study stated that service quality is vital for higher education institutions, including the people's perception of the services and how they are delivered [11].

The above description shows that customers' satisfaction is also an important indicator in measuring higher education quality.

\subsection{Education for Sustainable Development (ESD)}

Amaral et al. (2015) in Ozdemir et al. (2020) [12] stated since the 1970s sustainability concept has been on the list of the world and is being reviewed more and more extensively.

Research defined a sustainable university as follows [13]

"A higher educational institution, as a whole or as a part, that addresses, involves and promotes, on a regional or global level, the minimization of negative environmental, economic, societal, and health effects generated in the use of their resources to fulfill its function of teaching, research, outreach and partnership, and stewardship in ways to help society make the transition to a sustainable lifestyle."

The improvement of campus sustainability can be made by several forms, including education, green feature in building design, physical changes to existing infrastructure, and changes in facilities users' behavior that will reduce energy use [20]. Lozano et al. (2015) stated the number of universities and industries working together to contribute to sustainability continues to grow. However, most collaborative activities are based on "hard" technocentric solutions for environmental focus; only a few papers addressed "soft" issues in the organization. That paper proposed a new soft solution by developing an integrative course called Organizational Change Management for Sustainability (OCMS) [15].

Ozdemir et al. (2020) also indicated a need for an integrated approach that connects quality service and sustainability in Turkey's higher education. Their research also proposed an instrument called Sustainable Service Quality (SusServQual) [16]. The instrument adapted from Servqual [21] consists of five dimensions related to service quality and sustainability in a higher education institution, namely service to students, physical means, responsiveness, natural resources, and 
environmental sensitiveness. Moreover, a study showed that high-quality education in Europe could produce sustainable socio-economic developments [22].

Research by Medne et al. (2020) showed that higher education's sustainability development activities are possible to be integrated through quality system models and development approaches. The study stated that the quality system development approach, such as the European Foundation for Quality Management (EFQM) Excellence Model guides setting a strategic focus on sustainable development in higher education [15].

\section{Method}

A survey was conducted with respondents from faculty and study program leaders and lecturers who have been involved in the accreditation application process at a well-known private university in Indonesia. A total of 26 respondents have expressed their opinion. Questioners asked about the factors that can determine the quality of higher education. Respondents were asked to answer whether the factors mentioned were important in determining the quality of higher education and whether these factors were already included in the national accreditation criteria or not.

The factors mentioned are the accreditation rating; vision, mission, goals, and organizational strategy; governance; student academic achievement (example: GPA graduated on time); student non-academic achievement (example: art, sports); human resources (lecturers and administrative staff); finance and infrastructure; curriculum and the learning process; research, community service; student satisfaction; as well as education for sustainable development. The results showed that respondents consider all factors necessary by giving scores above 4 for the range of importance levels of 1 for very unimportant to 5 for significant (Figure 1).

Answering whether these factors are already available in the national accreditation criteria, most respondents stated that all factors had been included in the national accreditation criteria. However, student satisfaction with academic services is still considered insufficient; more than $50 \%$ of respondents stated that this factor is not listed in the national accreditation criteria. Even for the sustainability development factor, both in the curriculum, research, community service, and operational activities, as many as $50 \%$ to $80 \%$ of respondents stated that this factor was not available or was not yet available in the national accreditation criteria (Figure 2).

From this survey, it can be concluded that three main factors must be considered in determining the quality of higher education, namely national accreditation, which includes many factors, student satisfaction, student satisfaction in non-academic services, and issues of sustainable development. Student satisfaction and sustainable development factors need to be separately measured because the national accreditation criteria do not sufficiently cover them. Therefore, to get a comprehensive view of higher education quality, these three factors need to be considered. 


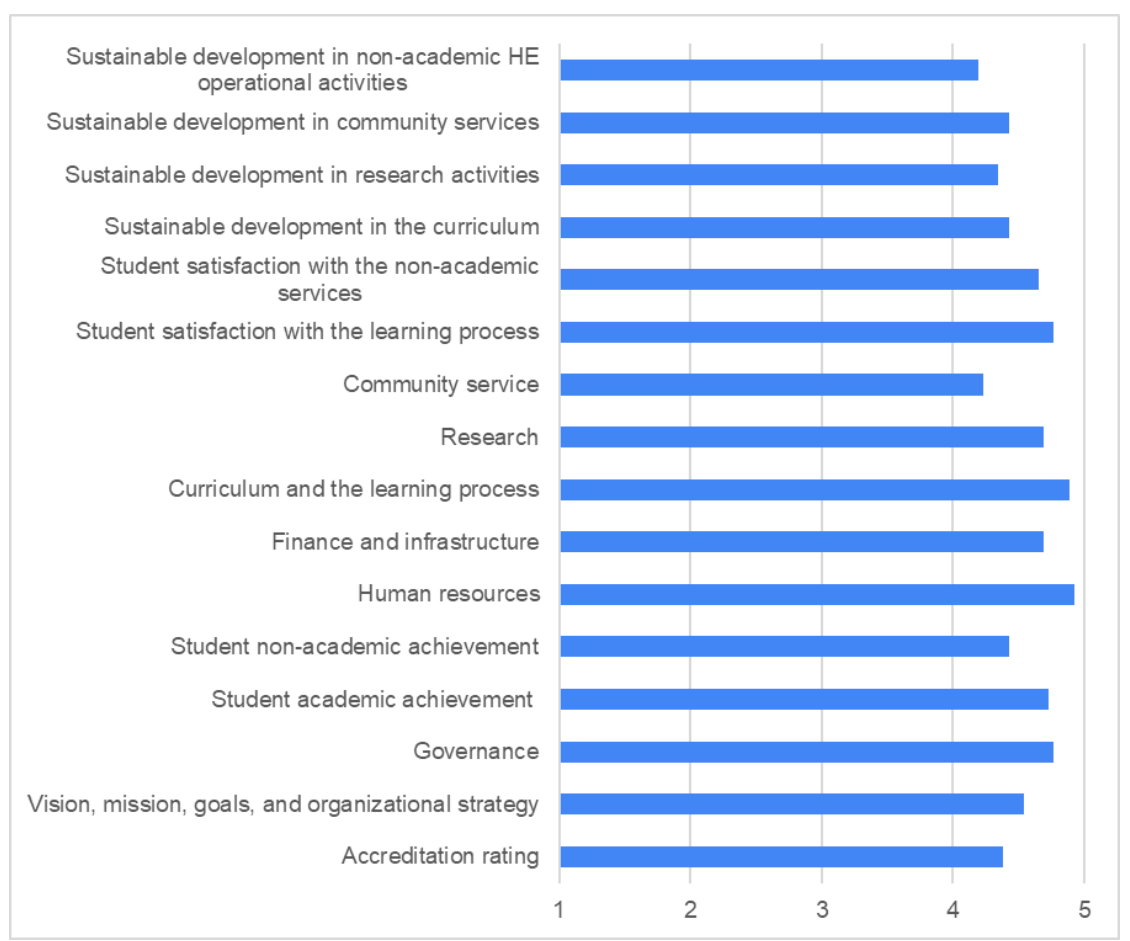

Fig. 1. The importance level of factors in determining the quality of higher education based on respondents' perceptions. 


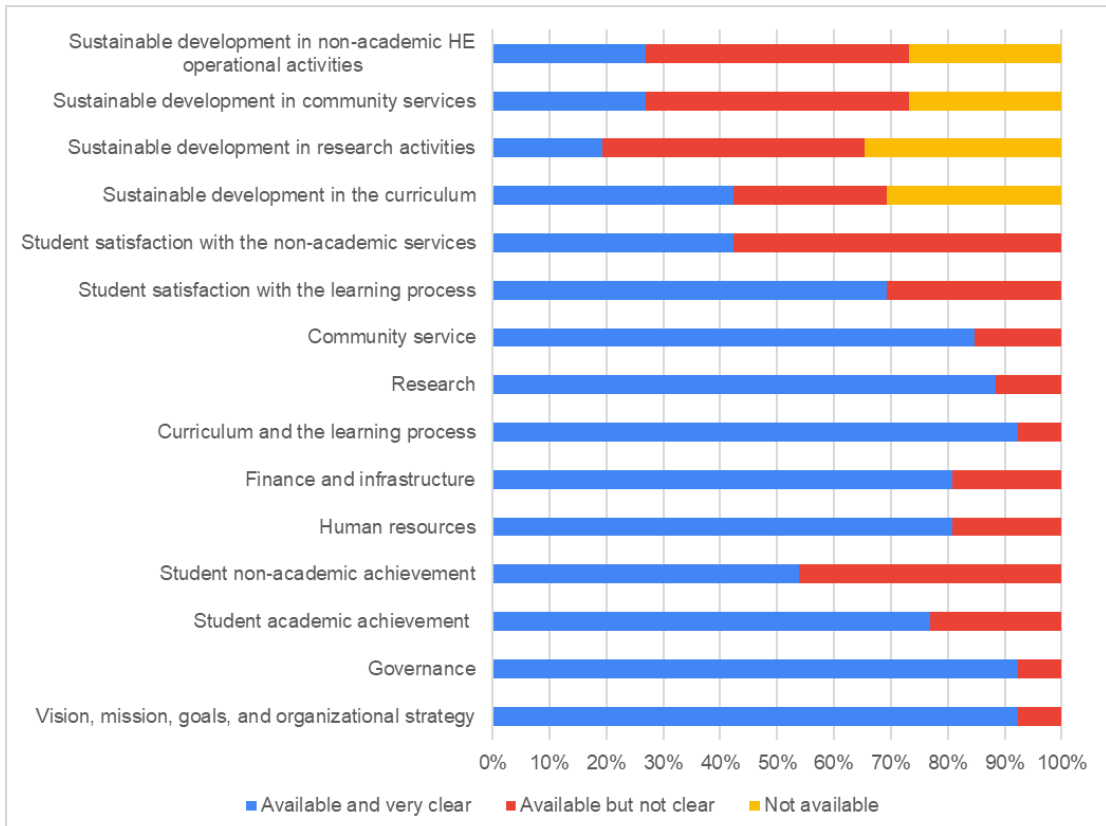

Fig. 2. Availability of factors in the national accreditation criteria.

\section{Results and Discussion}

\subsection{New proposed framework: 3 D ACS}

Learning from the quality assurance system in Romania and Omani [1, 23], there is an assumption that accreditation is seen as fulfilling the government's mandate and is perceived as a formality activity rather than for quality improvement. This means that the results of accreditation are not enough to demonstrate the quality of higher education adequately. Therefore, it is necessary to provide a more comprehensive measure of higher education quality using other perspectives.

Firstly, it is important to measure customer satisfaction. As mentioned above, the measurement of customer satisfaction with university stakeholders, including students, graduates, parents, industrial society, lecturers, and administrative staff, can be an accurate and reliable input for quality improvement. Therefore, customer satisfaction should be a concern for the university. Some universities are already doing it regularly. Another thing that needs to be considered is the appropriateness of the instruments used to measure customer satisfaction. Thus, universities must review customer satisfaction measurements and set the result side by side with their accreditation ratings. Logically, the accreditation ranking would be proportional to the customer satisfaction score. If not, it is necessary to examine the cause further. Measuring customer satisfaction will 
increase the comprehensiveness of the quality of higher education. Sukwadi et al. (2001) stated that tertiary education challenges mention that service quality attributes are needed to satisfy the students and are defined in service strategy improvement and development [24]. Adopting students' input on the institution's strategy improvement and development will ensure quality increasing at the institution.

Sukwadi \& Yang (2012) declared that many mechanisms had been adopted to evaluate and regularly review the quality of all facets of education services and propose frameworks for the quality of education services. Student satisfaction is a major driver of any organization's customer orientation, and higher education institutions are no exception. The research also presented a framework that would help meet their needs, lead to satisfaction and critical service attributes, and provide appropriate student perspectives [2]. The instruments for measuring higher education stakeholder satisfaction are available in several papers, for example, the Servqual instrument [9].

Secondly, the requirements to become a sustainable university that covers environmental, economic, and social can also become indicators of quality improvement. As stated above, highquality education can lead to the development of sustainable socio-economic. This statement also means that quality universities can contribute to sustainable development goals issued by the United Nations. Therefore, it is time for universities to realize the importance of implementing sustainability education in their activities. The activities referred to include "hard" solutions for environmental focus and "soft" issues covering management policies, behavior change, and education, including curricula. By including ESD as an indicator of quality measurement, universities will be more aware of implementing it. Measurement instruments for sustainable universities are also available in several papers; for example, SusServQual [25].

Previous studies [20 - 23] provide measurement results on these three perspectives separately. Based on these studies, it is crucial to systematically support accreditation as a quality measurement for a higher education institution. To enhance the overall quality, therefore, a 3-D ACS Framework was proposed in this study. Figure 3 shows a proposed model for measuring higher education institutions' quality that involves three perspectives, namely, accreditation, customer satisfaction, and ESD. 


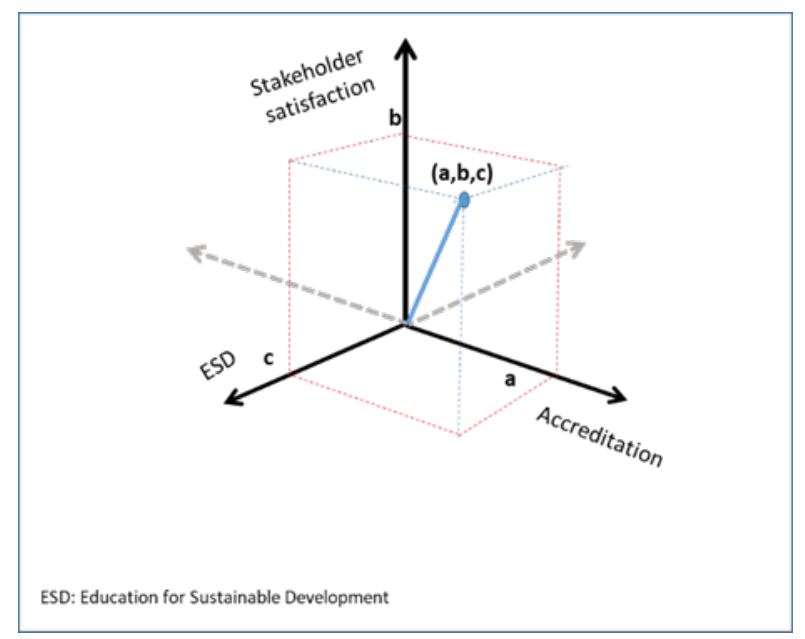

Fig. 3. 3-D of measuring higher education quality.

The coordinates $(a, b, c)$ reflect a new comprehensive measurement of the higher education institutions' quality. There will be eight different levels of quality. In-depth research is needed to put coordinate in each octane, whether weighting is required for each perspective. Also, the meaning of the eight levels of quality, their implications for higher education institutions, and other interested parties' impacts will be challenging topic research in the future.

Before arranging the 3-D model, it is essential to know the correlation between the three quality perspectives. Therefore, the first step that will be taken is to conduct research that will look for correlations between the three perspectives: accreditation, customer satisfaction, and sustainability education. The correlation between three quality perspectives will provide opportunities for further research to prove whether the quality level of one perspective can be predicted based on other perspectives. Figure 4 shows a potential research scheme that can be done, namely, to find the correlation between dimensions (accreditation, customer satisfaction, and ESD) and determine the weight/importance level of each dimension to the quality of higher education. This paper only presents the surface of the 3-D ACS Framework concept. Henceforth, in-depth research must be carried out to provide a more comprehensive concept of measuring higher education quality. 


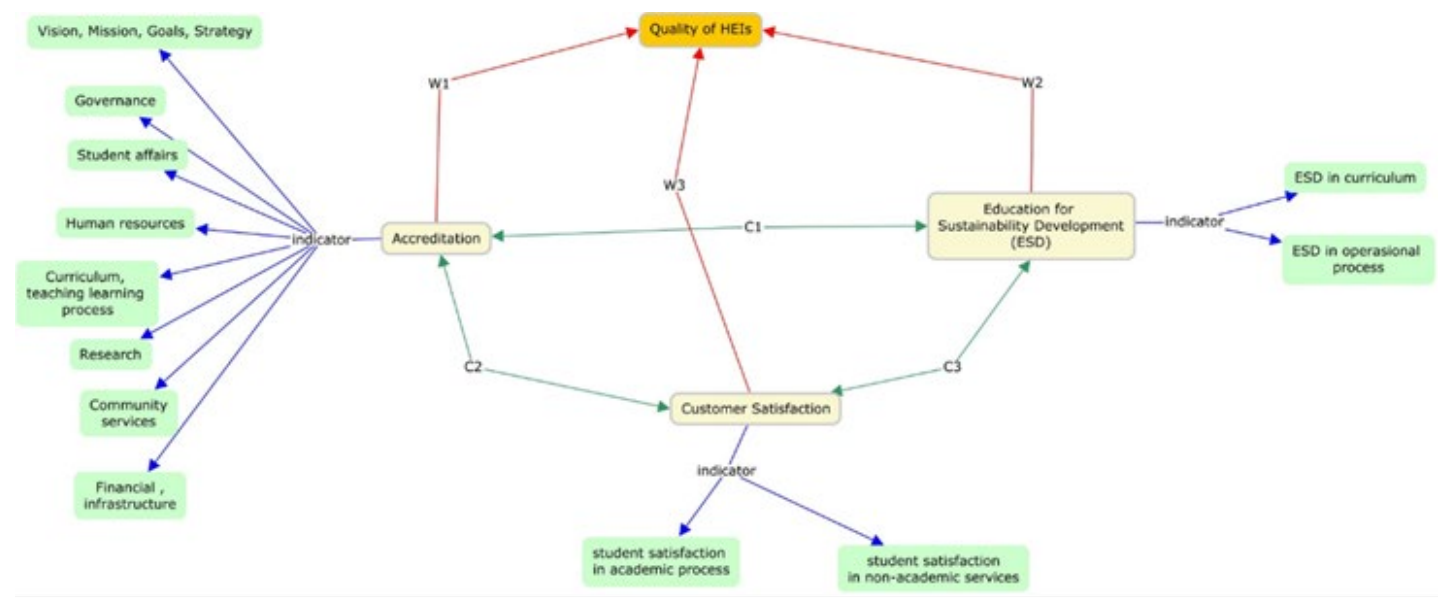

C1, C2, C3 : correlation between dimensions

W1, W2, W3: weight / level of importance of each dimension to quality

Fig. 4. Scheme of potential research could be done.

\subsection{New proposed framework: 3 D ACS}

The need to become a high-quality university is a demand for an institution, among others, to attract prospective students, international cooperation to absorb graduates into the workforce. One way that reflects the quality of higher education is accreditation, particularly accreditation mandated by the local government. The indicators in determining the accreditation ranking have covered many aspects, including vision, mission, goals, strategies, governance, curriculum and teaching-learning process, research performance, community service performance, human resources, student affairs, financial, and infrastructure. However, other aspects need to be considered in determining higher education quality, namely customer satisfaction and sustainability education. Customer satisfaction is deemed necessary because the measurement of customer satisfaction, in this case, students' satisfaction, can be accurate and reliable for quality improvement. On the other hand, higher education is also required to contribute to the United Nations' sustainability goals. The quality of higher education can contribute to the development of sustainable socio-economic development. Thus, a quality higher education institution should refer to sustainable education. Each of the three aspects, namely accreditation, customer satisfaction, and education for sustainable development, have their measurement criteria and instruments. However, the measurements are carried out separately. Therefore, a new framework is offered to provide measurement in determining higher education quality through these three aspects. This paper is an initial study and requires further indepth research to determine the relationship between these three aspects and determine the weight of each aspect to form a three-dimensional framework that includes accreditation, customer satisfaction, and sustainable education (3D ACS framework). 


\section{Conclusion}

A preliminary survey was conducted to identify important aspects of determining higher education quality. The results showed the accreditation requirements had already covered almost all aspects; however, it lacked student satisfaction and sustainable development education. The previous studies showed each perspective had been evaluated separately and has advantages and disadvantages. This paper proposes a novel quality framework consisting of three crucial perspectives: Accreditation ranking, Customer satisfaction, and education for sustainable development, which will be correlated with each other to obtain a comprehensive and holistic measure of the quality for a higher education institution. It is called the 3-D ACS Framework. This paper only presents the surface of the 3-D ACS Framework concept. Henceforth, in-depth research must be carried out to provide a more comprehensive concept of measuring higher education quality.

\section{References}

[1] Kecetep I, Ozkan I. Quality Assurance In The European Higher Education Area. $4^{\text {th }}$ World Conference On Learning Teaching And Educational Leadership; Barcelona - Spain. 2013.

[2] Gorea B, Saharov N. Legislative Bases for Quality Assurance in Romanian Higher Education. Global Conference on Contemporary Issues in Education; Las Vegas, USA. 2014.

[3] Sari A, Firat A, Karaduman A. Quality Assurance Issues in Higher Education Sectors of Developing Countries: Case of Nothern Cyprus. $5^{\text {th }}$ International Conference on Leadership, Innovation and Business Management; Istanbul - Turkey. 2016.

[4] Coates H, Shah M. The Rise of Quality Assurance in Asian Higher Education. Cambridge: Elseiver; 2017. The Growing Prominence of Quality Assurance in Asia; pp. xxi - xxx.

[5] Prasetyo H. Dampak Kebijakan Akreditasi Perguruan Tinggi terhadap Daya Saing (Competitiveness) Perguruan TInggi Swasta di Kabupaten Kebumen/Impact of Higher Education Accreditation Policies on Competitiveness of Private Higher Education in Kebumen Regency. Fokus Bisnis. 2014; vol. 13 (1): pp. 31-46.

[6] Widayat P. Peran akreditasi dalam menarik minat mahasiswa memilih perguruan tinggi swasta bermutu di Kota Pakan Baru/The role of accreditation in attracting students to choose quality private universities in Kota Pakan Baru. Penjaminan Mutu. 2018; vol. 4 (2): pp. 199-207.

[7] Yulianingsih Y. Manajemen akreditasi program studi pada perguruan tinggi/Management of accreditation of study programs at tertiary institutions. Al-Idarah. 2015; vol. 5 (1): pp. 92-116.

[8] Roga R, Lapina I, Muursepp P. Internationalization of Higher Education: Analysis of Factors Influencing Foreign Students' Choice. $20^{\text {th }}$ International Scientific Conference Economics and Management; Kaunas, Lithuania. 2015.

[9] Kooli C. Governing and managing higher education institutions: The quality audit contribution. J. Eval Program Plann. 2019; vol. 77: pp. 1-9.

[10] Yanova N. Assessment of Satisfaction with the Quality of Education: Customer Satisfaction Index. $4^{\text {th }}$ World Conference on educational Technology Researches; Barcelona. 2014.

[11] Belash O, Popov M, Ryzhov N, Ryaskov Y, Shaposhnikov S, Shestopalov M. Research on University Education Quality Assurance: Methodology and Result of Stakeholders' Satisfaction Monitoring. Worldwide trends in the development of education and academic research; Sofia-Bulgaria. 2015. 
[12] Dragan M, Ivana D, Arba R. Business Process Modeling in Higher Education Institutions, Developing a Framework for Total Quality Management at Institutional Level. $21^{\text {st }}$ International Economic Conference 2014 Sibiu; Romania, 2014. vol. 16, pp. 95-103.

[13] Espinoza O, McGinn N. Graduates' satisfaction as a measure of quality: Evidence from two programs in three Chilean universities. Int. J. Educ. Res. 2018; vol. 90: pp. 133-143.

[14] Holm T, Kaisu S, Vuorisalo T. Education for sustainable development and quality assurance in universities in China and the Nordic Countries: a comparative study. J. Clean. Prod. 2015; vol. 107: pp. 529-537.

[15] Ozdemir Y, Kaya S.K, Turhan E. A scale to measure sustainable campus services in higher education: "Sustainable Service Quality". J. Clean. Prod. 2020; vol. 245: pp. 1-17.

[16] Velazquez L, Munguina N, Platt A, Taddei J. Sustaiable university: what can be matter?. J. Clean. Prod. 200; vol. 14: pp. 810-819.

[17] ABET, Setting the standard worldwide, ed: ABET.

[18] Accreditation types and eligibility, ed: IABEE

[19] Eligibility process and application, ed: AACSB.

[20] Sukwadi R, Yang C.C. Determining Critical Service Attributes and Appropriate Improvement Actions in Indonesia HEIs. Ind. Eng. Man.Sys. 2012; vol. 11, no. 3: pp. 241-254.

[21] Faghihi V, Hessami A.R, Ford D.N. Sustainable campus improvement program design using energy efficiency and conservation. J. Clean. Prod. 2015; vol. 107: pp. 400-409.

[22] Lozano R, Ceulemans K, Seatter C.S. Teaching organizational change management for sustainability: designing and delivering a course at the University of Leeds to better prepare future sustainability change agents. J. Clean. Prod. 2015; vol. 106: pp. 205-215.

[23] Parasuraman A, Berry L.L, Zeithaml V.A. More on improving service quality measurement. J. Retail. 1993; vol. 69: pp. 140-147.

[24] Medne A, Lapina I, Zeps A. Sustainability of a university's quality system: adaptation of the EFQM excellence model. Int. J. Qual. Serv. Sci. 2020; vol. 12 (1): pp. 29-43.

[25] Sukwadi R, Yang C.C, Liu F. Towards an Identification and Classification of Service Quality Attributes in Higher Education. IJEEEE. 2011; vol. 1 (2): pp. 163-168. 